\title{
The Curious Case of Mervyn Eades: National Service, Discrimination and Aboriginal People
}

\author{
NOAH RISEMAN* \\ Australian Catholic University
}

In 1971, an Aboriginal man named Mervyn Eades was convicted for failing to register for national service. The magistrate determined that while Eades was indeed Aboriginal under Western Australian law, under the National Service Act he was not. Scrutiny of Eades' case exposes the interconnected issues of Aboriginality, racial discrimination, assimilation, federalism and conscription in the period between the 1967 Referendum and the 1972 election. Eades' conviction represented a unique junction of these seemingly disparate political issues which gradually converged. Analysis of Eades' case and the wider issue of Aboriginal people and national service highlights ongoing legislative discrimination in the immediate postReferendum period, the problematic status of concurrent Aboriginal affairs powers and the McMahon Liberal government's determination - ultimately unsuccessfully — to avoid conflation of conscription and race politics.

In 1971 an Aboriginal man from Western Australia named Mervyn Eades was charged for failing to register under the National Service Act. Eades argued in court that under section 18 of the Act, he was exempt from registering because he was Aboriginal. The question at trial became whether or not Eades could prove that he actually fit the definition of an "aboriginal native" prescribed in the National Service Act and its accompanying regulations. The Magistrate, H.J. Ryan, determined on 13 December 1971 that Eades was indeed Aboriginal under Western Australian law but not under the National Service Act. Ryan declared:

It is clear from the foregoing inconsistencies between the State and Commonwealth legislations that a person having an admixture of aboriginal blood of halfe [sic] caste or less than half caste could be an aboriginal native in Western Australia and yet under the National Service Regulations be not an aboriginal native. It seems to me possible also for such a person to be found to be an aboriginal native under the National Service Regulations and yet not be an aboriginal native under the Western Australian Act. ${ }^{1}$

Eades' conviction came at a critical time; the Vietnam War was winding down, the Commonwealth and Western Australian governments were trying to repeal de jure discrimination against Aboriginal people, the 1967 Referendum was still in recent memory and national service was a significant political issue. The Eades case was at

\footnotetext{
* The author gratefully acknowledges advice from colleagues at the Australian Catholic University, especially Shurlee Swain, Nell Musgrove and Maggie Nolan.

1 "At the Court of Petty Sessions Held at Albany Before H.J. Ryan, Esq., S.M. This $22^{\text {nd }}$ Day of November, 1971; Date of Decision: $13^{\text {th }}$ December, 1971, Between: Nigel Frederick Spitz, Commonwealth Police, Complainant, and Mervyn Eades, Defendant", in National Archives of Australia (hereafter NAA), series A2354, item 1968/1, Canberra.
}

(C) 2013 The Author.

Australian Journal of Politics and History (C) 2013 School of History, Philosophy, Religion and Classics, School of Political Science and International Studies, The University of Queensland and Wiley Publishing Asia Pty Ltd. 
the juncture of all these debates and highlighted the inconsistencies among political agendas, legislation and discriminatory definitions of Aboriginal people.

Mervyn Eades' case and the wider example of national service provide several points of analysis about ongoing legislative discrimination against Aboriginal people in the immediate post-1967 Referendum period. Legal definitions prescribing Aboriginality continued to discount Aboriginal agency and, as Eades' case epitomises, positioned Aboriginal people in continuing legal limbo. National service is a particularly useful prism because it is one area in which, arguably, excluding Aboriginal people worked in their favour. Eades' mere invocation of section 18 suggests that Aboriginal exemptions from national service relieved Aboriginal people of an onerous task. Yet documents indicate that bureaucrats, politicians, concerned citizens and both Indigenous and non-Indigenous organisations considered the explicit exclusion of Aboriginal people from national service to be a form of discrimination. Maintaining such discrimination in law contradicted governments' reform agendas of the 1960s and 1970s, aimed at stamping out formal discrimination.

Legislative changes included: extension of the Commonwealth franchise in 1962; social security to urban Aboriginal people in 1959; social security for all Aboriginal people in 1966; the 1967 Referendum counting Aboriginal people in the census and equal wages in 1968. Most states similarly worked to make Aboriginal people equal under the law; in Western Australia specifically, freedom of movement was extended in 1954, the franchise in 1962, the right to own property in 1963 and finally the right to drink liquor was granted in 1972. Despite progress in these areas, several Commonwealth laws - particularly those related to defence and national service continued to exclude Aboriginal people from equal treatment under the law. ${ }^{2}$ Documents reveal that the Commonwealth government recognised that they were discriminating against Aboriginal people, but they continued to do so under assumptions that excluding Aboriginal people from compulsory national service would never become a public relations problem. The growing unpopularity of the Vietnam War compounded the complex situation, whereby incorporating Aboriginal people into national service would expand the growingly unpopular scheme. Eades' case represented the culmination of these seemingly disparate issues, highlighting both continuing discrimination, as well as problems surrounding the concurrent state and federal powers over Aboriginal affairs.

To date the political intersections between Aboriginal affairs, national service, federalism, Vietnam and the anti-war/anti-conscription movement have not been adequately examined. To fill this gap in the historiography, archival material and newspaper articles about national service and Indigenous people have been utilised, as well as Aboriginal testimonies about national service. Mervyn Eades' particular case has only featured in Roberta Sykes' 1989 book Black Majority, albeit without significant analysis. Sykes republished an article entitled "Is Mervyn Eades White or Black?" from the Australian in 1971 to highlight the problems of differing state and federal definitions of Aboriginality. ${ }^{3}$ Only Ann-Mari Jordens has significantly analysed the topic of Aboriginal people and national service in her 1989 article "An Administrative Nightmare: Aboriginal Conscription 1965-72". Jordens argues that the

\footnotetext{
${ }^{2}$ See John Chesterman, Civil Rights: How Indigenous Australians Won Formal Equality (St. Lucia, Qld, 2005), p.67. Chesterman's book outlines all the other changes to legislation at the Commonwealth and state levels throughout the 1960s and 70s.

${ }^{3}$ Roberta B. Sykes, Black Majority (Hawthorn, Vic.), pp.10-12.
} 
federal government excluded Aboriginal people from national service because the Department of Labour and National Service (DLNS) considered it too difficult administratively to deal with Aboriginal people, particularly those from traditional backgrounds. ' Jordens' argument has merit but overlooks the issue of discrimination, the intersections between state versus federal policies and the problem of inconsistencies across the law. Peter Edwards' comprehensive book about Australia during the Vietnam War only briefly addresses the issue of Aboriginal people and national service. He summarises the administrative complications and concludes that "conscription of Aboriginals remained an unresolved issue, a constant source of potential, and at times actual, embarrassment for the authorities". ${ }^{5}$ Scholars who have addressed the topic of discriminatory legislation against Aboriginal people in the period 1967-72 include John Chesterman, Brian Galligan, Bain Attwood, Andrew Markus, Tim Rowse and, in Western Australia in particular, Tamara Hunter. ${ }^{6}$ These authors discuss the practical impacts (or lack thereof) of legislative changes up to and including the 1975 Racial Discrimination Act, but they do not adequately examine national service.

Analysis of Eades' case and the topic of Aboriginal people in national service contributes to the body of scholarly work about ongoing government discrimination against Aboriginal people and the problems of concurrent federal and state powers over Aboriginal affairs during the period between the 1967 Referendum and the 1972 election, which has been described as a period of transition at the end of the assimilation era. Eades' case represented a rare conjoining of multiple political issues plaguing the final years of the McMahon Liberal government: race relations, conscription and Vietnam. Eades' conviction publicly highlighted flaws in the national service scheme, legal discrimination against Aboriginal people, discontent with assimilation and the continuing unworkability of diverging state and federal prescriptions of Aboriginality. The Eades verdict and similar cases had the potential to catalyse an overhaul of national service eligibility, to contest assimilation policies by challenging static "definitions" of Aboriginality and to force federal and state governments to reconceptualise their concurrent powers over Aboriginal affairs. But events in 1972 such as the Tent Embassy and the subsequent election of the Whitlam Labor government halted the Eades case and others like it from ever gaining significant traction.

\section{Aboriginal People and National Service}

The 1960s were neither the first time conscription existed in Australia nor the first time that Aboriginal people were excluded. Under the Defence Act 1903 and amendments in 1910, Aboriginal people were explicitly exempt from call-up and from compulsory

\footnotetext{
4 Ann-Mari Jordens, “An Administrative Nightmare: Aboriginal Conscription 1965-72”, Aboriginal History, Vol. 13, 2 (1989), pp.124-134.

${ }^{5}$ Peter Edwards, A Nation at War: Australian Politics, Society and Diplomacy during the Vietnam War 1965-1975 (Sydney, 1992), p.79.

${ }^{6}$ Chesterman, Civil Rights; John Chesterman, "Defending Australia's Reputation: How Indigenous Australians Won Civil Rights, Part Two", Australian Historical Studies, Vol. 117 (2001), pp.201-221; John Chesterman and Brian Galligan, Citizens without Rights: Aborigines and Australian Citizenship (Cambridge, 1997); Bain Attwood, Rights for Aborigines (Sydney, 2003); Bain Attwood and Andrew Markus, The 1967 Referendum: Race, Power and the Australian Constitution (Canberra, 2007); Tim Rowse, Obliged to be Difficult: Nugget Coombs' Legacy in Indigenous Affairs (Cambridge, 2000); Tamara Hunter, "The Myth of Equality: The Denial of Citizenship Rights for Aboriginal People in Western Australia", Studies in Western Australian History, Vol. 22 (2001), pp.69-82.
} 
training. Australia's first implementation of conscription during the Second World War consequently excluded Aboriginal and Torres Strait Islander people. Nonetheless, approximately 3,000 Aboriginal people and 850 Torres Strait Islanders still voluntarily served in the Second World War. ${ }^{7}$ In 1951 the Menzies Liberal government introduced a new national service scheme, citing Communist disturbances in Southeast Asia and Korea. Section 18 of the National Service Act 1951 followed the Defence Act precedent and exempted Aboriginal people from registering for national service. ${ }^{8}$ There was little discussion in the media or government about their exclusion because Aboriginal affairs were not on the federal government's or public's agenda. The situation in the 1960s would be quite different.

The Menzies government passed an amended National Service Act in November 1964, reinstating what had been a defunct scheme since 1959. The government cited the need for national service because of the deterioration of the situation in Southeast Asia, including Indonesia's policies in Malaysia and the ongoing conflicts in Borneo and Vietnam. Among the people required to register for national service were almost all males aged twenty, including resident foreign nationals. Government notes stated that "[t]he same standards [i.e. intelligence, literacy], as apply to Regular soldiers, which are the lowest acceptable, will be applied to national servicemen". 9 Documents regularly asserted the equal applicability of national service; H.A. Bland, Department Secretary for DLNS, wrote in 1966 that "[t]he liability to register for national service applies equally to all young men of twenty years of age and it is essential therefore, in order to maintain equity between individuals, that liability for service should also remain universal". 10

Despite such claims to national service as an egalitarian scheme, there were regularly administrative exclusions and ambiguous interpretations which exempted

\footnotetext{
${ }^{7}$ Australia, Defence Act (as amended 1910), sections 61(1) (h) and 138(1) (b). For Aboriginal and Torres Strait Islander service in the Second World War, see Robert Hall, The Black Diggers: Aborigines and Torres Strait Islanders in the Second World War, 2nd ed. (Canberra, 1997); No Bugles, No Drums, produced by Debra Beattie-Burnett, directed by John Burnett, 49 min, Seven Emus Productions in association with Australian Television Network, 1990. Approximately 400 Aboriginal people also served in the First World War. For a historical overview of Aboriginal people in the armed forces, see Hugh Smith, "Minorities and the Australian Army: Overlooked and Underrepresented?" in Peter Dennis and Jeffrey Grey, eds, A Century of Service: 100 Years of the Australian Army. The 2001 Chief of Army's Military History Conference (Canberra, 2001), pp.129149.

${ }^{8}$ Australia, National Service Act 1951, section 18. For more on the introduction of national service in 1951, see Pam Maclean, "An Almost Universal Scheme of National Service in Australia in the 1950s", Australian Journal of Politics and History, Vol. 52, 3 (2006), pp.378-397.

9 "Notes on National Service", 18 November 1964, NAA, series A463, item 1964/5143 Part 1. For history of national service during the Vietnam era, see Christine Twomey, "The National Service Scheme: Citizenship and the Tradition of Compulsory Military Service in 1960s Australia", Australian Journal of Politics and History, Vol. 58, 1 (2012), pp.67-81; Edwards, A Nation at War, pp.20-25. For the experiences of national servicemen in Vietnam, see Paul Ham, Vietnam: The Australian War (Pymble, NSW, 2010), pp.165-177; Noel Wallis and Hugh Williams, Australia's Forgotten Forces - The Nashos (published and printed by Noel Wallis and Hugh Williams, 1996); Noel W. Wallis, Those Nashos! A brief account of National Service in Australia (published and printed by Noel W. Wallis, 1994).

${ }^{10}$ H.A. Bland, Secretary, Department of Labour and National Service, to Secretary, Prime Minister's Department, 28 November 1966, NAA, series A463, item 1964/5143 Part 2. Quotation also appears in letter from Harold Holt to all state premiers, 14 December 1966. For the applicability of foreign nationals, see also NAA, series A463, item 1962/3685 Part 1.
} 
various groups allegedly liable for national service. ${ }^{11}$ Aboriginal people, though, were the only civilian British subjects legally not required to register. The updated section 18 of the National Service Act again excluded "aboriginal natives of Australia, as defined by the regulations, other than a class of aboriginal natives as so defined that is specified in the regulations". ${ }^{12}$ Whereas in 1951 such clauses did not attract attention, as early as January 1965 the Commonwealth had to justify its position excluding Aboriginal people from conscription. Aboriginal affairs now garnered public interest because of domestic and global interest in minority civil rights. ${ }^{13}$ Bland defended the Government in May 1965:

there is no foundation for the suggestion that the Government intends any discrimination against Aborigines by reason of their not being required to register [...] it would be impracticable for many primitive or tribalised Aborigines to register and hence be liable for national service and to require this of them would create special hardship. ${ }^{14}$

As Jordens and Edwards emphasise, administrative difficulty and impracticability were recurring defences against repealing the references to Aboriginal people from the National Service Act. ${ }^{15}$ Moreover, the government regularly pointed out that Aboriginal people were only excluded from compulsory national service; they may still volunteer for national service, and an unknown number of Aboriginal people did. ${ }^{16}$

Calls for Aboriginal inclusion in compulsory national service came from various sectors of society, including politicians, concerned citizens, local councils, political party branches and Indigenous organisations. ${ }^{17}$ The first politician to raise the matter in Parliament was ALP Senator J. Fitzgerald, citing valiant Australian Indigenous and Papua New Guinean service in the Second World War as proof of their effective service. ${ }^{18}$ Individuals wrote letters to newspapers and politicians, claiming that the exemptions discriminated against Aboriginal people. One letter from a school child even asked: "are Aborigines conscripted for National Service. If not, why not? We feel

11 See Maclean, "An Almost Universal Scheme of National Service in Australia in the 1950s" pp.378-397.

${ }^{12}$ National Service Act 1964, section 18(e).

${ }^{13}$ See Chesterman, Civil Rights; Chesterman, "Defending Australia's Reputation: How Indigenous Australians Won Civil Rights, Part One”, Australian Historical Studies, Vol. 116 (2001), pp.20-39; Jennifer Clark, Aborigines and Activism: Race, Aborigines \& the Coming of the Sixties to Australia (Crawley, WA, 2008); Jennifer Clark, "The Wind of Change' in Australia: Aborigines and the International Politics of Race, 1960-1972", The International History Review, Vol. 20, 1 (March 1998), pp.89-117; Russell McGregor, Indifferent Inclusion: Aboriginal People and the Australian Nation (Canberra, 2011); Attwood, Rights for Aborigines.

${ }^{14}$ H.A. Bland, Secretary, Department of Labour and National Service, to Secretary, Prime Minister's Department, 7 May 1965, in NAA, series K38, item 1971/3551, Perth. Document also appears in NAA, series A463, item 1962/3685 Part 1, Canberra.

15 Jordens, "An Administrative Nightmare", pp.124-134; Edwards, A Nation at War, p.79. See various documents in: NAA, series A463, item 1968/3222, Canberra; NAA, series A2354, item 1968/1, Canberra; NAA, series K38, item 1971/3551, Perth; Australian War Memorial (hereafter AWM), series AWM263, item D/2/6; NAA, series A452, item NT1964/7194, Canberra; AWM, series AWM263, item D/2/7; State Records Office of Western Australia (hereafter SRO), series 2030, item 1965/0317, Perth.

${ }^{16}$ See various documents in AWM, series AWM263, item D/2/6. See also newspaper articles in SRO, series 2030, item 1965/0317, Perth.

17 Jordens, "An Administrative Nightmare", pp.125-126.

18 "Native Call-Up Demand", Canberra Times, 29 January 1965, in AWM, series AWM263, item $\mathrm{D} / 2 / 6$. 
that if we are striving for their welfare, they should be given equal treatment wherever it is possible". ${ }^{19}$ Other letters advocated national service for "lazy" Aboriginal people on the grounds that national service would "[p]rovide a new sense of responsibility and national spirit". ${ }^{20}$ Local councils and other individuals similarly argued that discipline would benefit Aboriginal people in their wider communities. ${ }^{21}$ Even the Federal Council for the Advancement of Aborigines and Torres Strait Islanders (FCAATSI) resolved in 1965 " $[\mathrm{t}]$ hat the Federal Council call upon the Commonwealth Government to remove discriminatory clauses against Aborigines in the National Service Act". ${ }^{22}$ In Western Australia in particular, several branches of the Liberal and Country Parties proposed the repeal of the references to Aboriginal people from the National Service Act. In 1967 the Western Australia State Liberal Conference endorsed a motion to that effect. $^{23}$ From 1965 through 1971, the Commonwealth-State Aboriginal Welfare Conferences regularly called for Aboriginal inclusion in national service on equal terms. ${ }^{24}$ Such calls fit with the assimilation agenda of the period, with government policies and practices promoting that Aboriginal people should live in the same manner as all other Australians. ${ }^{25}$

Aboriginal people, too, expressed opposition to the discriminatory provisions in the National Service Act. As mentioned, several Aboriginal people voluntarily signed up

${ }^{19}$ Sue Ping, Kempsey NSW, fourth form History student, to Minister for the Interior, 1 October 1971, in NAA, series A2354, item 1968/1, Canberra.

${ }^{20}$ David Michael, "Exemption of Natives from Conscription", West Australian, 8 February 1965, in SRO, series 2030, item 1965/0317, Perth. See also S.K. Randell, "Platform", West Australian, 15 February 1965; S.K. Randell, "Equality for Aborigines", West Australian, 17 February 1965; Miss Barbara Stewart, Gnowwangerup, WA, to Minister for Labour and National Service, no date, early 1969, in NAA, series K38, item 1971/3551, Perth; Miss Sharyn Capewell, Grenville, NSW, to Minister for Labour and National Service, 15 March 1971, in NAA, series A2354, item 1968/1, Canberra.

21 “N.S. Urged for Natives", West Australian, 17 July, 1967, in SRO, series 2030, item 1965/0317; Mrs. N.G. Moir, to Officer-in-charge, National Service Training, 28 September 1965, in NAA, series K38, item 1971/3551, Perth; B.G. Dexter, Director, to the Secretary, Department of Labour and National Service, 29 February 1972, in NAA, series A2354, item 1968/1, Canberra.

${ }^{22}$ Stan Davey, Hon. General Secretary, The Federal Council for Advancement of Aborigines and Torres Strait Islanders, to The Hon. A.J. Forbes, M.C., M.P., Minister for the Army, 2 November 1965, in AWM, series AWM263, item D/2/6. For other Indigenous organisations, see F.E. Gare, Commissioner of Native Welfare, WA, to the Director, Department of Labour and National Service, 17 March 1969, in SRO, series 2030, item 1965/0317; document also appears in NAA, series K38, item 1971/3551, Perth and NAA, series A2354, item 1968/1, Canberra. For FCAATSI, see Sue Taffe, Black and White Together: FCAATSI: The Federal Council for the Advancement of Aborigines and Torres Strait Islanders 1958-1973 (St Lucia, Qld, 2005); Jack Horner, Seeking Racial Justice: An Insider's Memoir of the Movement for Aboriginal Advancement, 1938-1978 (Canberra, 2004); Faith Bandler, Turning the Tide: A Personal History of the Federal Council for the Advancement of Aborigines and Torres Strait Islanders (Canberra, 1989).

23 “Aborigines Wanted In Call-Up", West Australian, 4 July 1967, in NAA, series K38, item 1971/3551, Perth; document also appears in SRO, series 2030, item 1965/0317; "Libs urge Aborigines for call-up", Daily News, 3 July 1967, in SRO, series 2030, item 1965/0317. See also F.J. Martin, to Secretary, Federal Parliamentary Country Party, 29 March 1971, in NAA, series K38, item 1971/3551, Perth.

24 NAA, series A452, item NT1964/7194, Canberra; NAA, series A452, item NT1967/2081, Canberra; B.G. Dexter, Director, to The Secretary, Department of Labour and National Service, 29 February 1972, in NAA, series A2354, item 1968/1, Canberra.

${ }^{25}$ See Anna Haebich, Spinning the Dream: Assimilation in Australia, 1950-1970 (North Fremantle, 2008); McGregor, Indifferent Inclusion; Tim Rowse, ed. Contesting Assimilation (Perth, 2005). 
for national service, and some did so as a form of protest. Yorta Yorta Vietnam veteran Graham Atkinson testifies: "I thought, y'know, in terms of being equal, that uh, was sort of discriminative. So, um, I was aware that technically, I um, didn't have to enrol [in national service]. But I thought, y'know, that time as a young bloke, who had a lot of friends who were conscripted too [...]". ${ }^{26}$ Western Australian Aboriginal veteran John Schnaars describes how originally DLNS refused his application:

Yep. Got a letter back saying that they didn't want me, no, no explanation, so I wrote them another letter then saying, well this is gonna look good in the media, I'm, I'm volunteering for National Service and you're knockin' me back and you're forcing others to go in that don't want to go in. So it was about two to three weeks later got another letter saying, go for your medical. And that was that. ${ }^{27}$

Unlike Eades, who used the discriminatory provisions of the National Service Act to try to avoid national service, these and other Aboriginal men drew attention to national service discrimination and volunteered as a matter of equal rights. Opposition to the racial provisions of the National Service Act thus came from a cross-section of society throughout the duration of national service. Nonetheless, because national service was not a priority in Indigenous affairs, this opposition did not attain a critical mass.

In response to public calls for Aboriginal inclusion in national service, DLNS argued that the provisions of the National Service Act only applied to certain "nomadic" classes of Aboriginal people. Those who lived more settled lifestyles could still be obligated to register for national service if they did not fit the definition of Aboriginal laid out in the National Service Regulations. Regulation 18 defined an Aboriginal person as:

(a) a full-blooded aboriginal native of Australia;

(b) a person who is a half-caste aboriginal native of Australia or has an admixture of aboriginal blood greater than a half-caste; or

(c) a person who has an admixture of aboriginal blood and lives as an aboriginal native or amongst aborigines. ${ }^{28}$

The complex definition of Aboriginality was meant to appear non-prejudicial whilst still discriminating. For instance, the original 1951 National Service Act only excluded "aboriginal natives of Australia as defined by the regulations", whereas the 1964 Act added the phrase "other than a class of aboriginal natives as so defined that is specified in the regulations". ${ }^{29}$ Bland wrote that "[o]ne reason for this amendment was to counter any charges of discrimination against aborigines". ${ }^{30}$ Historian Pam Maclean argues that

\footnotetext{
${ }^{26}$ Graham Atkinson, interviewed by George Bostock, April 1991, Australian Institute for Aboriginal and Torres Strait Islander Studies (AIATSIS), item BOSTOCK_G01-016549, Canberra.

27 John Schnaars, interviewed by Noah Riseman, 23 November 2010, Perth, in National Library of Australia (hereafter NLA), ORAL TRC 6260/1. See also John Schnaars, in “The Last Post," Message Stick, directed by Adrian Wells, produced by the Australian Broadcasting Corporation (ABC), 2006, DVD.

${ }^{28}$ National Service Act Regulations, 1964, section 18.

29 "Aboriginal Welfare Conference 1965, Liability of Aborigines to Register for National Service", submitted by the Department of Territories, 22 July 1965, in AWM, series AWM263 D/2/6; document also appears in NAA, series A452, item NT1964/7194, Canberra.

${ }^{30}$ H.A. Bland, Secretary, Department of Labour and National Service, 6 December 1965, in NAA, series K38, item 1971/3551, Perth. See also H.A. Bland, Secretary, Department of Labour and National Service, to Secretary, Prime Minister's Department, 7 May 1965, in NAA, series A463, item
} 
the real purpose of such a complex definition of Aboriginality in the National Service Regulations was so that Aboriginal people "should only be called up if their fellow conscripts considered them to be 'acceptable', in other words fully assimilated". 31 During the assimilation period after the Second World War, those Aboriginal people who, in the government's eyes, "assimilated", usually ceased to be Aboriginal under law. Thus the classifications of Aboriginality aligned perfectly with the government assimilation agenda of the 1960s.

The flaw with the government's position was that providing a stipulated definition of Aboriginality did not circumvent discrimination or promote assimilation; rather, not counting all Aboriginal people merely compounded the discrimination. Bureaucrats and politicians recognised this in their internal memos. Regular correspondence between DLNS and the Council for Aboriginal Affairs (formed after the 1967 Referendum) deliberated the prospect of removing references to Aboriginal people from the National Service Act and administratively excluding "tribalised" Aboriginal people. Arguments for such change focused on public opinion, international obligations and the Liberal government's pronounced agenda to repeal discrimination from all federal legislation to promote assimilation. ${ }^{32}$ Indeed, as historian Tim Rowse writes, it was the goal of the Council for Aboriginal Affairs to end "differences in the treatment of Aboriginals and other citizens". ${ }^{33}$ DLNS dismissed the Council for Aboriginal Affairs' suggestions on two grounds: firstly, it would be too much of an administrative burden, and secondly, it would merely introduce discrimination into the administrative process. ${ }^{34}$ By 1970 DLNS accepted the inclusion of Aboriginal people in compulsory national service as part of its agenda, but stated "there is no intention of opening up general discussion of the Act by introducing amendments relating only to Aborigines". 35

\section{Federalism and Aboriginality: Conflicting Definitions}

As the internal debates waged over whether or not to amend the National Service Act, there were also concerns across the different states about the applicability of the definition of Aboriginality. As early as 1965, the Victorian Superintendent of Aborigines Welfare flagged:

there is a variety of interpretations in this State as to whether or not a part-Aboriginal who lives in a house with other part-Aborigines is liable for registration or not [...] What is the test to be

1962/3685 Part 1, Canberra; Reply to CWA WA letter, 9 March 1966, in AWM, series AWM263, item $\mathrm{D} / 2 / 7$.

${ }^{31}$ Maclean, "An Almost Universal Scheme of National Service in Australia in the 1950s", p.394.

32 Numerous documents in: NAA, series A2354, item 1968/1, Canberra; AWM, series AWM263, item D/2/6; AWM, series AWM263, item D/2/7; NAA, series A452, item NT1964/7194, Canberra. For the impact of international obligations on Indigenous policy, see Chesterman, Civil Rights; Chesterman, "Defending Australia's Reputation" Parts One and Two; Clark, Aborigines \& Activism; Clark, "“The Wind of Change", pp.89-117; McGregor, Indifferent Inclusion.

${ }^{33}$ Rowse, Obliged to be Difficult, p.29.

34 Memo from C.E. Reseigh, for Secretary, Department of Territories, to The Secretary, Prime Minister's Department, 15 January 1968, in NAA, series A463, item 1968/3222, Canberra; document also appears in NAA, series A2354, item 1968/1, Canberra.

35 P.H. Cook, Secretary, Department of Labour and National Service, to The Director, Office of Aboriginal Affairs, 19 February 1970, in NAA, series A2354, item 1968/1, Canberra. 
applied as to whether a part-Aboriginal is living 'as an Aboriginal native' or 'amongst Aborigines'. Is the Department influenced by the State definition of 'Aborigines' [...] [?]

The fact that each state had a different definition of Aboriginal people complicated matters further, as an individual could be deemed Aboriginal in some states but not others; this had led to legal complications on several occasions when Aboriginal people crossed borders, ${ }^{37}$ and varying definitions led to confusion both across and within states. The South Australian Department of Aboriginal Affairs reported in 1969: "there is no legitimate way in which the caste can be proved with any degree of certainty. As a result, an Aboriginal, who in fact should register for National Service in accordance with the National Service Act, may fail so to register and there appears to be no method whereby he can be required to do so" ${ }^{38}$ Victorian and New South Wales officials expressed similar difficulties determining which Aboriginal people would fit under the National Service Regulations definition. ${ }^{39}$ Queensland, on the other hand, had a larger Aboriginal population and a stronger regime of segregation, making the definition of Aboriginality more "workable". The DLNS Regional Director in Queensland wrote: "[1]ittle difficulty should be experienced in complying with registration requirements" ${ }^{40}$ The Northern Territory and Western Australia similarly presumed that there would be few Aboriginal people liable for national service due to both the predominantly "tribalised" population, but also the poor literacy skills of Aboriginal people of mixed descent. ${ }^{41}$ Ironically, Eades came from a state with a larger Aboriginal population and which considered that it would have no problem classifying Aboriginal people, whereas the south-eastern states with larger mixed-descent Aboriginal populations were able to foresee problems assessing the Aboriginality of potential candidates for national service.

Auditing the situation in 1966, DLNS received reports from state welfare departments approximating the number of Aboriginal people who may be eligible for

36 P.E. Felton, Superintendent of Aborigines Welfare, Aborigines Welfare Board, to Director, Department of Labour and National Service, Melbourne, 11 August 1965, in AWM, series AWM263, item $\mathrm{D} / 2 / 6$.

${ }^{37}$ See Chesterman and Galligan, Citizens without Rights, pp.113-115; 121-155. See also Peter Read, "Whose Citizens? Whose Country?" in Nicolas Peterson and Will Sanders, eds, Citizenship and Indigenous Australians (Cambridge, 1998), pp.169-178; Aboriginal and Torres Strait Islander Commission, As a Matter of Fact: Answering the Myths and Misconceptions about Indigenous Australians (Canberra, 1998), p.60.

38 C.J. Millar, Director of Aboriginal Affairs, Department of Aboriginal Affairs, Adelaide, to B.G. Dexter, Director, Office of Aboriginal Affairs, Canberra, 24 March 1969, in NAA, series A2354, item 1968/1, Canberra.

39 P.E. Felton, Superintendent of Aborigines Welfare, Aborigines Welfare Board, to Director, Department of Labour and National Service, Melbourne, 11 August 1965; R.A. Smee, Regional Director, New South Wales, Department of Labour and National Service, to P.H. Cook, First Assistant Secretary, Department of Labour and National Service, 16 December 1965. Both documents in AWM, series AWM263, item D/2/6.

40 A. Gibson, Regional Director, Queensland, Department of Labour and National Service, to P.H. Cook, First Assistant Secretary, Department of Labour and National Service, 10 December 1965, in AWM, series AWM263, item D/2/6.

${ }^{41}$ G.E. McGregor, Assistant Registrar, Perth, 19 January 1966, "Memo for File"; F.H. Moy, for Secretary, Department of Territories, to The Secretary, Department of Labour and National Service, 10 May 1966. Both documents in AWM263, item D/2/6. 
national service under existing regulations. ${ }^{42}$ The diverging state responses did not raise concerns among DLNS staff; instead, the audit reinforced DLNS's false assumptions that individuals could easily fit into the categories of "Aboriginal" or "non-Aboriginal" under the National Service Regulations. Various parties external to DLNS raised the alarm about potential complications arising from the definition of Aboriginality. B.G. Dexter, the Director of the Office of Aboriginal Affairs, wrote in 1968: "[n]o definition or judicial discretion has been made on the actual meaning of the phrases 'lives as an Aboriginal' or 'lives amongst Aboriginals", 43 The South Australian Department of Aboriginal Affairs wrote in 1969: "[i]t would appear from discussions with Aboriginal Affairs officers, National Service authorities and the Aboriginals themselves, there is no clear understanding of the subject". ${ }^{4}$ DLNS continually brushed aside such criticism on the grounds that Aboriginal people who wished to serve may sign up voluntarily. They thus continued to assume that the discriminatory nature of the National Service Act centred on excluding Aboriginal people. They did not figure that discrimination could also cause problems if Aboriginal people not fitting the prescribed definition failed to register, such as Mervyn Eades.

Eades' case was not the first involving confusion over an Aboriginal person failing to register for national service. Victorian Aboriginal Vietnam veteran Glen James recalls:

I was twenty when I got a notice to say I was called up for National Service. Then I got a notice to say I didn't need to go because I was Aboriginal. Then I got a third notice to say I had to go after all. I tell you, that put a damp outlook on the whole thing right from the start. I was going, then I wasn't going and they'd raised this question of Aboriginality right at the start. ${ }^{45}$

In 1968, a Western Australian man named Stephen Henry presented himself at registration, self-identifying as a "half-caste", but was told that he still had to register. Henry consulted a lawyer and managed to produce a family tree showing that he was slightly more than "half-caste" under Western Australian law. When the state Department of Native Welfare supported Henry's claim, DLNS ruled that he was not liable for call-up. ${ }^{46}$ In 1970, Queenslander and Rugby League World Cup contender Eric Simms was nearly prosecuted for failing to register because he thought himself exempt as a "part-Aboriginal" man. A press release from DLNS declared: "I am satisfied after careful enquiry by my officers that Mr Simms, at the time he was obliged to register or National Service, was under the impression that he was not a person affected by the National Service Act". ${ }^{47}$ Simms was ultimately allowed to register without penalty and was treated the same as all other Australians registered for national

\footnotetext{
${ }^{42}$ G. Sutcliffe, Department of Labour and National Service Minute, "Liability of Aborigines for National Service", 2 March 1966, in AWM, series AWM263, item D/2/6. See also Jordens, "An Administrative Nightmare", pp. 127-128.

${ }^{43}$ B.G. Dexter, Director, Office of Aboriginal Affairs, to the Minister, 1 May 1968, in NAA, series A2354, item 1968/1, Canberra.

${ }^{44}$ C.J. Millar, Director of Aboriginal Affairs, Department of Aboriginal Affairs, Adelaide, to B.G. Dexter, Director, Office of Aboriginal Affairs, Canberra, 24 March 1969, in NAA, series A2354, item 1968/1, Canberra.

${ }^{45}$ Glen James, in Alick Jackomos and Derek Fowell, eds, Forgotten Heroes: Aborigines at War from the Somme to Vietnam (South Melbourne, Vic, 1993), p.67.

${ }^{46}$ Documents in NAA, series K38, item 1971/3551, Perth.

${ }^{47}$ Department of Labour and National Service News Release, "National Service - Eric J. Simms", 6 October 1970, in AWM, series AWM263, item D/2/7.
} 
service. These cases were minor and resolved without litigation, thus postponing Commonwealth and state governments having to confront the inconsistent, discriminatory nature of the National Service Act and its accompanying regulations. Eades' case, though, would finally heighten public awareness of the problematic status of Aboriginal people under national service.

\section{The Case of Mervyn Eades}

Mervyn Eades was born in 1949, living his first ten years in tents at the Kojonup Native Reserve in south-west Western Australia, and then with Aboriginal people at Westfield, Tembellup and Cranbrook Native Reserves. In 1965 he moved into transitional housing built by the Western Australian Native Welfare Department. From 1969 Eades resided with his de facto wife and three children in Cranbrook in a house not on the Native Reserve, but owned by the Native Welfare Department. Under Western Australia law, Eades was classified as "three-eighths caste" and thus an Aboriginal person under The Native Welfare Act 1963. ${ }^{48}$ But "three-eighth" did not constitute "Aboriginal" under the National Service Regulations because it was less than "half-caste". When charged with failing to register for national service, Eades thus had to prove that he fit the definition of Aboriginal under regulation 18(c) as "a person who has an admixture of aboriginal blood and lives as an aboriginal native or amongst aborigines". 49

Eades argued that throughout his life he regularly associated only with Aboriginal people and that his associations with whites were only to the extent that all Aboriginal people had to confront the realities of contemporary Australia. He attended schools compulsorily but did not play or associate with white children. Eades argued that the white community in Cranbrook discriminated against him, not allowing him to play pool and regularly ostracising him. Yet the magistrate focused less on Eades' treatment and associations and more on his lifestyle. Magistrate Ryan affirmed that Eades had previously fit the definition of Aboriginal under the National Service Regulations. Ryan concluded, though, that Eades ceased to fit the definition of Aboriginal when he moved into a house with his de facto "quarter-caste" wife. Ryan declared, "the defendant has looked after this house in the same manner as the average white citizen would care for a like house [...] [and] conducts himself in a manner acceptable to responsible white citizens in his area". 50 That Eades held a regular job, dressed well, owned a car and spoke English thus implied to the magistrate that Eades did not live as an Aboriginal man because he had successfully "assimilated". He was convicted and fined twenty dollars for failing to register for national service. ${ }^{51}$

\footnotetext{
48 "At the Court of Petty Sessions Held at Albany Before H.J. Ryan, Esq., S.M. This $22^{\text {nd }}$ Day of November, 1971; Date of Decision: $13^{\text {th }}$ December, 1971, Between: Nigel Frederick Spitz, Commonwealth Police, Complainant, and Mervyn Eades, Defendant", in NAA, series A2354, item 1968/1, Canberra. For Western Australia's legislative regime over Aboriginal people, particularly after the Second World War, see Hunter, "The Denial of Citizenship Rights for Aboriginal People in Western Australia”, pp.69-82; Chesterman, Civil Rights, pp.124-147.

${ }^{49}$ National Service Regulations, 1964, section 18.

50 "At the Court of Petty Sessions Held at Albany Before H.J. Ryan, Esq., S.M. This $22^{\text {nd }}$ Day of November, 1971; Date of Decision: $13^{\text {th }}$ December, 1971, Between: Nigel Frederick Spitz, Commonwealth Police, Complainant, and Mervyn Eades, Defendant", in NAA, series A2354, item 1968/1, Canberra.

${ }^{51}$ Ibid. See also various newspaper articles in: NAA, series A2354, item 1968/1, Canberra; NLA, item 1862902, Canberra; NAA, series A1734, item NT1972/23, Canberra.
} 
The press reported Eades' conviction and focused primarily on the absurdity of Eades being classified as Aboriginal under Western Australian law but not the National Service Act. Coverage in the Australian article "Is Mervyn Eades Black or White?" summarised the situation: "[b]ut it was possible for a person to be deemed Aboriginal under West Australian law but not an Aboriginal under the national service regulations, and vice versa". ${ }^{52}$ A scathing editorial in the Australian declared:

The State of Western Australia is satisfied that Mr Eades is an Aboriginal. The Commonwealth is not. Its reason is that he cannot be so long as he is well dressed, speaks English, lives in a house like a Housing Commission one and drives a car. His wife is even less black to look at than he is, so he cannot be said to be living with Aboriginals. Therefore, he must be white.

This is the kind of egregious nonsense that goes on in hearings in South Africa under the Immorality Act in which ethnic origins are minutely examined to prevent any chance of racial cross-hatching. It is incredible that it can be used as a serious, straight-faced line of argument in an Australian court. ${ }^{53}$

Press coverage of Eades' case condemned the magistrate's static primitive interpretation of "real" Aboriginal people. Yet the media did not adequately address the discriminatory provisions in the National Service Act. Media coverage seemed to interpret the fundamental problem to be the inconsistent and unfair definitions of Aboriginal people, without commenting on the interrelated fact that being Aboriginal was an excludable factor from national service.

Newspaper coverage of the Eades verdict was significant enough to worry the Commonwealth government. J.E. Cooper of the Office of Aboriginal Affairs wrote: "we are now in a position where the courts are saying when an Aboriginal is an Aboriginal [...] It would be preferable to make all Aborigines exempt compared to the present situation where many young Aborigines don't know whether they should register or not. This must be a considerable worry and prosecution can be seen as gross injustice." ${ }^{, 54}$ Cooper's statement is interesting because he pointed out that courts were deciding who was and was not Aboriginal. This had been a practice common across the states since the introduction of protection laws in the late $1800 \mathrm{~s} .{ }^{55}$ That it was still happening in 1971, though, contradicted the pronounced anti-discrimination goals of the Commonwealth and state governments and betrayed the sentiments (albeit not the practical implications) of the 1967 Referendum.

The press also inadvertently recognised a critical issue often lost in public memory about Aboriginal civil rights: the ineffectiveness of the 1967 Referendum. The Australian accurately reported:

After the 1967 referendum, most of us assumed that the Commonwealth had the power to make special laws to help Aboriginals. One of these laws was the exemption of Aboriginals from having to do national service. But, judging by the result of the Eades case, this power will only be applied

\footnotetext{
52 "Is Mervyn Eades Black or White?" Australian, 15 December 1971. Document appears in: NAA, series A2354, item 1968/1, Canberra; NLA, item 1862902, Canberra; NAA, series A1734, item NT1972/23, Canberra; Sykes, Black Majority, pp.10-12.

53 "Marking the Color Line", Australian, 16 December 1971. Document appears in: NAA, series A2354, item 1968/1, Canberra; NAA, series A1734, item NT1972/23, Canberra.

54 J.E. Cooper, Senior Research Officer II, Office of Aboriginal Affairs, "National Service Act", 15 March 1972, in NAA, series A2354, item 1968/1, Canberra.

${ }^{55}$ See Read, “Whose Citizens? Whose Country?”, pp.169-178.
} 
in certain circumstances [...] Australians overwhelmingly demanded an end to this kind of bias through their vote in the 1967 referendum. ${ }^{56}$

As the Eades case highlighted, granting the federal government concurrent powers to pass legislation in relation to Aboriginal people did not standardise the state regimes or definitions of Aboriginal people. Certainly, as Chesterman has indicated, most states were moving towards a uniform repeal of restrictive legislation through the 1960s and early 1970s. ${ }^{57}$ Yet the Commonwealth government had been hesitant to use its new race powers to override state definitions of Aboriginality, and consequently the varying definitions and statuses continued to co-exist. ${ }^{58}$

The timing of Eades' case also coincided with the rise of Black Power and new selfassertions of Aboriginality. ${ }^{59}$ Attwood writes that the term "Aboriginality" came to prevalence among young Aboriginal activists in the post-Referendum period as an affirmation of their cultural pride and identity. They argued that they were Aboriginal because of both their pre-colonial and continuing cultural connections in Australia. ${ }^{60}$ Aboriginal people had regularly rejected definitions based on blood quanta since the implementation of protection legislation, and the Eades case represented merely another confrontation between government definitions versus Indigenous assertions of their own Aboriginality.

From 1968 the Commonwealth Minister responsible for Aboriginal Affairs William Wentworth — was already in the process of adopting a more favourable definition of Aboriginality based on cultural connections rather than blood quanta. ${ }^{61} \mathrm{By}$ August 1972, the Commonwealth definition for the purposes of any special assistance programs read: "[a]n Aboriginal is a person of Aboriginal descent who claims to be an

56 "Marking the Color Line". For the ineffectiveness of the Referendum, see Larissa Behrendt, "What Did the 'Yes' Vote Achieve? Forty Years after the 1967 Referendum", Senate Occasional Lecture Series at Parliament House, 29 June 2007; Attwood and Markus, The 1967 Referendum, especially pp.65-85.

${ }^{57}$ Chesterman, Civil Rights, pp.103-176.

58 The lack of significant change after the 1967 Referendum has been a theme analysed in the following: Russell McGregor, "Another Nation: Aboriginal Activism in the Late 1960s and Early 1970s", Australian Historical Studies, Vol. 40 (2009), pp.343-360; McGregor, Indifferent Inclusion, pp.162-182; Attwood, Rights for Aborigines, pp.307-349.

59 For Black Power in Australia, see Gary Foley, "Black Power in Redfern 1968-1972", The Koori History Website, <http://www.kooriweb.org/foley/essays/essay_1.html>, accessed 14 December 2011; Ann Turner, ed., Black Power in Australia: Neville Bonner versus Bobbi Sykes (South Yarra, VIC, 1975); Kathy Lothian, "Seizing the Time: Australian Aborigines and the Influence of the Black Panther Party, 1969-1972”, Journal of Black Studies, Vol. 35, 4 (March 2005), pp.179-200; Kathy Lothian, "Moving Blackwards: Black Power and the Aboriginal Embassy" in Ingereth Macfarlane and Mark Hannah, eds, Transgressions: Critical Australian Indigenous Histories (Acton, ACT, 2007), pp.19-34; Kathleen Lothian, “'A blackward step is a forward step': Australian Aborigines and Black Power, 1969-1972", thesis for Master of Arts, School of Historical Studies, Monash University, 2002; McGregor, Indifferent Inclusion, pp.162-182; McGregor, “Another Nation”, pp.343-360; Clark, Aborigines and Activism, pp.203-243; Embassy Days, aired as an episode of Message Stick, Australian Broadcasting Corporation, 2008; Ningla-a-na: Hungry for Our Land, produced and directed by Alessandro Cavadini, Melbourne: Australian Film Institute, 1972.

${ }^{60}$ Attwood, Rights for Aborigines, pp.315-321.

61 Jordens, "An Administrative Nightmare", p.129. See also Andrew Markus, "Australian Governments and the Concept of Race: An Historical Perspective" in Marie de Lepervanche and Gillian Bottomley, eds, The Cultural Construction of Race (Annandale, NSW, 1988), pp.56-59. For more on Wentworth and Indigenous Affairs, see Lachlan Clohesy, "Australian Cold Warrior: The Anti-Communism of W. C. Wentworth”, PhD Thesis (Victoria University, 2010), pp.276-309. 
Aboriginal and is accepted as such by the community with which he is associated" ${ }^{62} \mathrm{~A}$ few months after Eades' conviction, the repeal of The Native Welfare Act in Western Australia reclassified the Western Australian definition to be a person "wholly or partly descended from the original inhabitants of Australia who claims to be an Aboriginal and who is accepted as such". ${ }^{63}$ Under these revised definitions, Eades most certainly would be considered an Aboriginal man under both Commonwealth and Western Australian laws. Yet DLNS refused to accept Wentworth's definition and did not wish to amend the criteria laid out in the National Service Regulations. As Jordens summarises, "the Department was hamstrung by the old, outdated and unworkable definition". ${ }^{4}$ DLNS argued that their department was not defining who was and was not Aboriginal, but merely " $\mathrm{t}]$ heir sole purpose is to specify categories of Aborigines who, for the reasons mentioned above, are exempt from national service obligations and, by definition, to specify those who are not exempt" ${ }^{65}$ The focus on "categories" reflected the assimilationist agenda of classifying only Aboriginal people who had sufficiently "assimilated" — such as Eades — as suitable for national service. This semantic attempt to avoid the question of "definitions" through an emphasis on "categories" represented another DLNS attempt to avoid confronting the matter of discrimination in the National Service Act.

\section{The Vietnam Context}

Despite DLNS memoranda focusing on the potential administrative difficulties regarding Aboriginal people and national service, the social context of the Vietnam War and the anti-war/anti-conscription movements cannot be divorced from DLNS determinations. As early as 1968, when DLNS and the Council of Aboriginal Affairs acknowledged discrimination in the National Service Act, public servants were advocating "that the National Service Act should not be amended specially for this purpose but that the amendment be introduced when other amendments are put before the Parliament". ${ }^{66}$ This recurring excuse suggests that the Liberal government did not want to introduce amendments to an increasingly unpopular national service scheme. By March 1968, conscripts comprised almost half of Australia's forces in Vietnam. As Michael Hamel-Green argues, public opinion polls by 1969 had turned against the Vietnam War, and consequently the Liberal government proceeded cautiously on any issue involving national service or Vietnam. The draft resistance movement gathered significant momentum after Labor's loss in the 1966 election, and from 1970 it gained

${ }^{62}$ A. Stephen to Mr. Kangan, $1^{\text {st }}$ Assistant Secretary, "Departmental Definition of "Aboriginal'”, 31 August 1972, in AWM, series AWM 263, item D/2/6. For more on the politics of definitions between the 1966 and 1971 censuses, see Tim Rowse and Len Smith, "The Limits of 'Elimination' in the Politics of Population", Australian Historical Studies, Vol. 41, 1 (2010), pp.90-106.

${ }^{63}$ Chesterman and Galligan, Citizens without Rights, p.188. See also A. Stephen, to Mr. Kangan, $1^{\text {st }}$ Assistant Secretary, "Departmental Definition of 'Aboriginal", 31 August 1972. These two similar definitions represented precursors to the three-part definition of Aboriginal people accepted nationally since the High Court ruling Commonwealth v. Tasmania in 1983. See As a Matter of Fact, p.60.

64 Jordens, “An Administrative Nightmare”, p.130.

${ }^{65}$ A. Stephen, to Mr. Kangan, $1^{\text {st }}$ Assistant Secretary, "Departmental Definition of 'Aboriginal”, 31 August 1972.

66 F.H. Moy, Department of Aboriginal Affairs, 31 January 1968, in NAA, series A2354, item 1968/1, Canberra. 
wider mainstream support from academia, religious organisations, the media and even the ALP. ${ }^{67}$

The government ultimately broke its promises to consider the Aboriginal question the next time that amendments to the National Service Act were on the agenda. In late 1971 the government amended the Act to reduce national service from two years to eighteen months, hoping to ameliorate public opposition to conscription. ${ }^{68}$ The amended tenure of national service was meant to foster the appearance of reducing conscription in Australia. To amend the National Service Act at the same time to include Aboriginal people would appear to be widening the national service scheme. DLNS worried that adding Aboriginal people into the national service scheme would merely contribute to the anti-war movement. P.H. Cook, Secretary of DLNS, wrote in 1972:

(c) with the then identification of national service with Vietnam it would doubtless be said that the Government had now reached the stage where it was even calling up Aborigines to fight in Vietnam;

(d) there was, indeed, the real risk that while Australian troops remained in Vietnam successful attempts would be made to join and exploit what have been separate protest causes, namely Vietnam and Aboriginal rights; ${ }^{69}$

The Council for Aboriginal Affairs concluded: “[o]n the whole, Labour and National Service's reply does not indicate that they are anxious to amend the Act at all, despite the fact that they were so 'upset' by the Mervyn Eades case". ${ }^{70}$ Removing the racial provisions would have ended another form of legal discrimination, but in the process Aboriginal people including Eades would then have to sign up for national service anyway.

${ }^{67}$ For histories of the anti-conscription and anti-war movements, see Michael E. Hamel-Green, "The Resisters: A History of the Anti-Conscription Movement 1964-1972" in Peter King, ed., Australia's Vietnam: Australia in the Second Indo-China War (North Sydney, 1983), pp.100-128; Ann-Mari Jordens, "Conscription and Dissent: The Genesis of Anti-War Protest" in Gregory Pemberton, ed., Vietnam Remembered (Sydney, 1990), pp.60-81; John Murphy, Harvest of Fear: A History of Australia's Vietnam War (St Leonards, NSW, 1993), pp.211-232; Greg Langley, A Decade of Dissent: Vietnam and the Conflict on the Australian Home Front (North Sydney, 1992), pp.34-43; Donald Horne, Time of Hope: Australia 1966-72 (London, 1980), pp.51-60; Ann Curthoys, "The Anti-War Movements" in Jeffrey Grey and Jeff Doyle, eds, Vietnam: War, Myth and Memory: Comparative Perspectives on Australia's War in Vietnam (St. Leonards, NSW, 1992), pp.81-107; Edwards, A Nation at War, pp.76-85; 212-235; 275-281; 307-316; Robin Gerster and Jan Bassett, Seizures of Youth: "The Sixties" and Australia (South Yarra, Vic., 1991), pp.88-91; Hugh Smith, "Conscientious Objection to Particular Wars: Australia's Experience during the Vietnam War, 19651972", War and Society, Vol. 8, 1 (May 1990), pp.118-134; Malcolm Saunders, "The ALP's Response to the Anti-Vietnam War Movement: 1965-73", Labour History, Vol. 44 (May 1983), pp.75-91; idem, “'Law and Order' and the Anti-Vietnam War Movement: 1965-72”, Australian Journal of Politics and History, Vol. 28, 3 (1982), pp.367-379.

${ }^{68}$ Hamel-Green, "The Resisters", p.117. See also P.H. Cook, Secretary, Department of Labour and National Service, to Director, Office of Aboriginal Affairs, 3 March 1972, in NAA, series A2354, item 1968/1, Canberra.

69 P.H. Cook, Secretary, Department of Labour and National Service, to Director, Office of Aboriginal Affairs, 3 March 1972, in NAA, series A2354, item 1968/1, Canberra. See also Jordens, "An Administrative Nightmare", pp.130-131.

70 J.E. Cooper, Senior Research Officer II, Office of Aboriginal Affairs, "National Service Act", 15 March 1972, in NAA, series A2354, item 1968/1, Canberra. 
After the Eades case and the government's obstinate refusal to amend the National Service Act or its regulations, another case in Western Australia resulted in the conviction of Stanley Ward for failing to register for national service. Similar to Eades, Ward argued that he had been raised as an Aboriginal man, associated principally with Aboriginal people and had confronted racism throughout his life. He also argued that he was an Aboriginal rights activist and that his sister was the recipient of a Commonwealth scholarship reserved for Aboriginal people. The magistrate in Ward's case used similar assimilationist criteria applied in the Eades case and determined: " $[\mathrm{t}]$ he defendant lives in what is apparently a normal address, he is well dressed. There has been no suggestion he lives in a camp, and he apparently lived in a house in Derby. The defence hasn't established to my satisfaction that he comes under Regulation $18 c$ ". ${ }^{71}$ Ward's verdict in June 1972 received even more publicity than the Eades case. $^{72}$ It sparked letters criticising the narrow, assimilationist view of Aboriginality, with statements such as "[p]resumably if Stan had painted his face and done a rain dance in the court he would have been all right. But he didn't. He behaved like a man proud of his race. For his pains, he was stripped of his dignity — and $\$ 40 " 73$ Jordens suggests that the Ward case revealed problems with the self-definition of Aboriginal people introduced by Wentworth. ${ }^{74}$ More accurately, though, cases such as Ward's and Eades' highlight the continuing inconsistent approaches to Aboriginal definitions in the early 1970s, the unfair assimilationist interpretation of "real" Aboriginality and the problem of concurrent federal and state powers over Indigenous affairs.

The government's desire to avoid the conflation of anti-Vietnam and Aboriginal rights protests became untenable when convictions such as Eades' and Ward's brought public attention to the intertwined issues. An editorial published in the Australian argued, "[i]f ever there were fertile ground for the seeds of its own destruction it is in the administrative, legal and social swamp that has developed around Aboriginals and national service". ${ }^{75}$ Realising the government's worst fears, anti-draft activists also publicised the problematic status of Aboriginal people in relation to national service. Prominent draft resister Robert Muntz wrote a satirical letter in the Australian, arguing, "it was high time that whites were given equal rights with Aboriginals in this matter, by abolishing the offensive and racially based law requiring whites to register for national service". ${ }^{76}$ Muntz's piece spooked DLNS. The issue of discrimination in national service had come full circle; Eades', Ward's and others' failed attempts to use the racial provisions of the National Service Act to avoid national service had revealed

${ }^{71}$ F.E.A. Bateman, S.M., "Hearing of a Charge under Section 48 1(b) - National Service Act Stanley Robert WARD”, Perth Court of Petty Sessions 21 June 1972, Mr. F.E.A. Bateman S.M. Magistrate, in AWM, series AWM263, item D/2/7.

72 "SM - Remark not Meant to Offend", Daily News, 22 June 1972, p. 3; "Aboriginal Should get Benefit of Doubt", Daily News, 22 June 1972, p. 3; "Remarks were compliment, not insult, says SM", unclear newspaper or date; "Call-up fine for well dressed quarter-caste", Sun, 22 June 1972; "N.S. case: Defence of part-native rejected", West Australian, 22 June 1972; "An Aboriginal may not Wear a Suit", Truth, 1-8 July 1972. Articles all appear in AWM, series AWM263, item D/2/7. "Black or White' Court Riddle", The Sun, 22 June 1972, in NAA, series A2354, item 1968/1, Canberra.

73 "An Aboriginal may not Wear a Suit".

74 Jordens, “An Administrative Nightmare”, p.131.

75 "When is an Aboriginal not one? When he's a conscript", Australian, 24 June 1972, in AWM, series AWM263, item D/2/7.

76 Secretary, Department of Labour and National Service Minute, "National Service; Robert MUNTZ", 30 June 1972, in AWM, series AWM263, item D/2/6. 
the discriminatory nature of the Act for all Australians. These fraught debates had the potential to further foment the Black Power and anti-war movements. Just as the issue was gaining traction, though, the election of the Whitlam Labor government in December 1972 nipped such protests in the bud. Stanley Ward appealed his conviction and in December 1972 a court stayed his appeal indefinitely. ${ }^{77}$ Whitlam's government subsequently repealed the National Service Act in 1973, and the discriminatory provisions ended with the demise of national service. ${ }^{78}$

\section{Conclusion}

On 23 April 1971, a statement by Prime Minister William McMahon was read at the Cairns Conference of Ministers Responsible for Aboriginal Affairs. His statement declared:

I am happy to inform Ministers that discussions with the States, following the agreement reached at this conference a year ago to examine remaining legislation which appears to discriminate against Aborigines, have proceeded amicably and promise well for a successful outcome. When these discriminations in law are gone, it will be our task (with, I believe, the support of the great mass of the Australian people) to move towards complete enjoyment of normal civil liberties by Aborigines generally. ${ }^{79}$

Despite McMahon's proclamation, Mervyn Eades was convicted a few months later because of the extant discriminatory provisions in the National Service Act and its accompanying regulations. This discrimination against Aboriginal people remained enshrined until the Act's demise. As Jordens writes, "[t]he Government refused to amend the legislation, probably at first because it thought the problem was a minor one (or because it was influenced by those believing an administrative solution was possible), and later because for political reasons it wanted to avoid opening up the whole issue of conscription". ${ }^{80}$

Mervyn Eades' case exposed another example of both discrimination and problems stemming from concurrent powers over Aboriginal affairs in the immediate postReferendum period. Even though the government recognised continuing legislative discrimination, they steadfastly refused to amend the National Service Act for political reasons surrounding the Vietnam War, never anticipating such a case would arise and lead to a conviction. These false assumptions about national service and Aboriginal people not only overlooked liberal egalitarian principles, but they also rejected Aboriginal assertions of self-identity, continuing to adhere to assimilationist ideologies of what constituted Aboriginality. Mervyn Eades became a casualty of such discrimination, but his case concurrently exposed the flaws in both national service and Aboriginal affairs in the dying days of the McMahon Liberal government.

77 M.D. Robertson, Regional Director, Department of Labour and National Service Minute, To Secretary, Melbourne, Attention Mr. Watcher, 20 December 1972, in AWM, series AWM263, item $\mathrm{D} / 2 / 7$.

78 NATIONAL SERVICE TERMINATION ACT 1973, No. 88, assented to 21 June 1973. See also Edwards, A Nation at War, pp.318-320.

79 "Statement by Prime Minister to Cairns Conference of Ministers Responsible for Aboriginal Affairs, $23^{\text {rd }}$ April 1971", in NAA, series A1851, item 1971/508, Canberra.

${ }^{80}$ Jordens, "An Administrative Nightmare", p.133. 